\title{
Fourth Ventricular Neurocytoma: Case Report and Review of the Literature
}

\author{
Douglas J. Cook, Sean D. Christie, Robert J.B. Macaulay, \\ Dorianne E. Rheaume, Renn O. Holness
}

\begin{abstract}
Objectives: Central neurocytoma is a tumour that typically occurs in young adults in close association with the lateral and third ventricles of the cerebrum. Methods: We report the unusual case of a central neurocytoma that developed in the fourth ventricle of a 59-year-old woman and metastasized to the upper cervical canal. Subtotal excision and adjuvant radiotherapy were used to treat the lesion. Microscopic evaluation, discussion of the pathologic differential diagnosis and theories of the histogenesis of the tumour are presented. Results and Conclusions: Fourth ventricular neurocytoma is rare and has only been reported twice previously. It appears most likely that this tumour arises from subependymal progenitor cell lines.
\end{abstract}

RÉSUMÉ: Neurocytome du quatrième ventricule: cas clinique et revue de la littérature. Objectifs : Le neurocytome central est une tumeur habituellement localisée aux ventricules latéraux et au troisième ventricule, qui survient typiquement chez les jeunes adultes. Méthodes : Nous rapportons le cas inusité d'un neurocytome central qui s'est développé dans le quatrième ventricule chez une femme de 59 ans, avec métastase au canal cervical supérieur. Elle a été traitée par excision sub-totale de la tumeur et radiothérapie. Nous présentons les constatations anatomopathologiques et nous discutons du diagnostic différentiel histologique et des théories concernant l'histogenèse de la tumeur. Résultats et conclusions : Le neurocytome du quatrième ventricule est une pathologie rare dont deux cas seulement ont été rapportés. Cette tumeur provient vraisemblablement de lignées cellulaires progénitrices sous-épendymaires.

Can. J. Neurol. Sci. 2004; 31: 558-564

Central neurocytoma $(\mathrm{CN})$ was originally described by Hassoun et al, ${ }^{1}$ in 1982 and has since been included in the World Health Organization Classification of Tumors of the Central Nervous System. ${ }^{2}$ The occurrence of $\mathrm{CN}$ is rare, accounting for between 0.1 and $0.5 \%$ of all primary central nervous system neoplasms. ${ }^{3,4}$ Classically, this tumor arises in the lateral ventricle from the septum pellucidum or corpus callosum during the second to third decade of life and has a benign course. ${ }^{5,6}$ Radiologically the tumor usually has a lobulated appearance with areas of calcification and is well-demarcated with appreciable enhancement. ${ }^{6,7}$ Histologically it is characterized by round to ovoid cells with short processes and immunohistochemical and ultrastructural evidence of neuronal differentiation. ${ }^{1,8-11}$ Cases of extraventricular $\mathrm{CN}$ have rarely been reported. ${ }^{12-17}$ In this case report we present a fourth ventricular neurocytoma with drop metastases to the upper cervical spinal cord, arising in a 59-year-old woman who was ultimately treated with surgery and radiation. We can find only two previous reports of fourth ventricular neurocytoma (Table). ${ }^{18,19}$

\section{Case Report}

This 59-year-old previously healthy woman presented with a history of intermittent morning headaches and nausea. A $1.5 \mathrm{~cm}$ fourth ventricular mass was found on CT scanning. Magnetic resonance imaging (MRI) showed a round, lobular mass measuring 1.7 x 1.9 × 2.2 $\mathrm{cm}$ in the lower aspect of the fourth ventricle (Figure 1). There was a central signal void within the mass suggestive of either calcification or cyst formation and a slight heterogeneous enhancement with gadolinium. Although the fourth ventricle rostral to the mass was slightly dilated, no hydrocephalus was noted. At the patient's request, clinical and MRI follow-up was arranged. An MRI five months later

From the University of Toronto, Division of Neurosurgery, Hospital for Sick Children, Toronto, Ontario, (DJC); Division of Neurosurgery, (SDC, ROH); and the Department of Pathology (RJBM); Queen Elizabeth II Health Sciences Centre, Nova Scotia Cancer Centre, (DER); Halifax, Nova Scotia, Canada

ReCEIVED DeCEMber 8, 2003. ACCEPTED INFINALFORM June 21, 2004 Reprint requests to: Renn O. Holness, Division of Neurosurgery, Room 3806, 1796 Summer Street, Queen Elizabeth II Health Sciences Centre, Halifax, Nova Scotia, Canada B3H 2 Y9 
Table: Summary of previous cases of fourth ventricular neurocytoma reported in the literature

\begin{tabular}{|c|c|c|c|}
\hline Patient Characteristics & Present Case & Hsu et al. 2002 & Warmuth-Metz et al. 1999. \\
\hline Age & 58 & 35 & 17 \\
\hline Sex & Female & Male & Male \\
\hline Clinical features & $\begin{array}{l}\text { Headache, nausea, nystagmus, impaired } \\
\text { gait. }\end{array}$ & $\begin{array}{l}\text { Morning headache, visual } \\
\text { "blurring," papilledema. }\end{array}$ & $\begin{array}{l}\text { Ataxia, visual disturbance, } \\
\text { papilledema }\end{array}$ \\
\hline Radiologic Finding & $\begin{array}{l}\text { MRI- Heterogeneously enhancing mass in } \\
\text { the fourth ventricle. } \\
\text { signal suggestive of calcification, } \\
\text { no hydrocephalus. }\end{array}$ & $\begin{array}{l}\text { MRI- Heterogeneously enhancing } \\
\text { cystic lesion in the fourth ventricle. } \\
\text { CT- Hydrocephalus, no } \\
\text { calcification noted }\end{array}$ & $\begin{array}{l}\text { MRI- Homogenously enhancing } \\
\text { lesion from fourth ventricular floor } \\
\text { CT- Central calcification, } \\
\text { hydrocephalus }\end{array}$ \\
\hline Surgical Findings & $\begin{array}{l}\text { Vascular tumour from the floor of the } \\
\text { fourth ventricle. } \\
\text { Seeding present. } \\
\text { Partial resection. }\end{array}$ & $\begin{array}{l}\text { Circumscribed tumour arising from } \\
\text { floor of the fourth ventricle. } \\
\text { Complete resection. }\end{array}$ & $\begin{array}{l}\text { Seeding of tumour apparent } \\
\text { locally. Partial resection. }\end{array}$ \\
\hline Pathologic Findings & $\begin{array}{l}\text { Monomorphic round cells, eosinophilic } \\
\text { cytoplasm, delicate processes. NSE } \\
\text { positive, Synaptophysin and GFAP } \\
\text { negative. Low Ki-67 index. }\end{array}$ & $\begin{array}{l}\text { Uniform round cells, perinuclear } \\
\text { halo, within a fibrillary matrix. } \\
\text { Synaptophysin and NSE positive, } \\
\text { GFAP negative. }\end{array}$ & $\begin{array}{l}\text { Monomorphic round cell tumour. } \\
\text { Synaptophysin positive. MIB-1 } \\
>2 \% \text {. }\end{array}$ \\
\hline Follow-up & $\begin{array}{l}\text { Post-op MRI- residual tumour and } \\
\text { enhancing area at the spinomedullary } \\
\text { junction. Disseminated craniospinal } \\
\text { radiotherapy totaling } 3600 \text { cGy with an } \\
\text { additional } 2000 \text { cGy boost to tumour bed. }\end{array}$ & Not included & $\begin{array}{l}\text { Recurrence, second incomplete } \\
\text { resection, CN confirmed with } \\
\text { MIB-1 of } 10 \% \text {. Conventional } \\
\text { radiotherapy } 50.4 \text { Gy. }\end{array}$ \\
\hline Outcome & $\begin{array}{l}\text { Left sixth and seventh nerve palsies,", } \\
\text { depression post-operatively. Improvement } \\
\text { in tumour bed enhancement and resolution } \\
\text { of enhancing area at the spinomedullary } \\
\text { junction }\end{array}$ & Not included & Neck ataxia and post-op dysphagia \\
\hline
\end{tabular}

demonstrated a slight increase in lesion size and enhancement as compared to the previous exam (Figure 1). Again, no hydrocephalus could be appreciated and she remained relatively asymptomatic. However, over the next two months she had two episodes of severe morning headache, nausea and vomiting and developed limited upward gaze. On examination there was a right-beating nystagmus and difficulty in tandem gait. An MRI demonstrated further growth of the fourth ventricular lesion, measuring $2.6 \times 2.4 \times 2.3 \mathrm{~cm}$ (Figure 1). She was started on oral corticosteroids and underwent urgent resection of the lesion after she deteriorated, developing weakness of the lower limbs, visual blurring, headache, photophobia and left upper limb dysmetria. A midline occipital craniectomy was performed allowing access to the foramen of Magendie where the tumor was visualized. The tan grey tumor arose from the floor of the fourth ventricle and infiltrated the roof of the ventricle. There was obvious tumour seeding of the adjacent ventricle and cerebellum. Complete gross resection of the highly vascular tumor was not possible. Postoperative examination revealed a dense left facial palsy, loss of left lateral gaze, normal trigeminal function and a positive left Bell's reflex. The patient developed a small left corneal abrasion, so her left eyelid was fitted with a gold weight. An MRI prior to discharge demonstrated residual tumor in the fourth ventricle (Figure 2) and a small nodule attached to the ventral medulla (Figure 3).

\section{Surgical Pathology}

The tumour was moderately to highly cellular arranged in patternless sheets with delicate, profuse vascular supply (Figure 4). Cells possessed pale eosinophilic cytoplasm with delicate processes and vascular proliferation. Cell nuclei were monomorphic and round with delicate salt and pepper chromatin pattern. Mitotic activity was not observed and there was limited, but demonstrable perinuclear halo effect.

Immunohistochemical staining revealed irregular vasculature on reticulin staining, strong positive staining for neuron-specific enolase, and negative staining for synaptophysin, neurofilament and glial fibrillary acidic protein (Figure 4). Ultrastructural analysis revealed occasional Golgi apparati and few electron dense bodies. Processes were short and stubby containing mitochondria, vesicles and endoplasmic reticulum. However, no specific synaptic vesicles or intermediate 


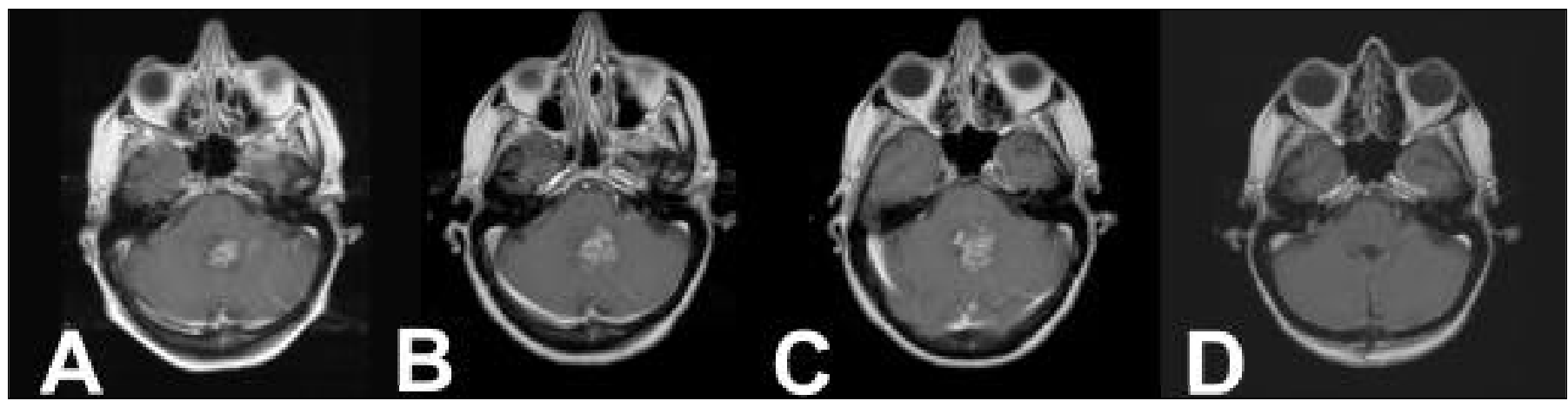

Figure 1: Serial Gadolinium enhanced T1 images of the fourth ventricular lesion. Images correspond to tumour appearance at presentation (A), at 5 months following presentation (B), 10 months following presentation $(C)$ and postoperatively $(D)$. The mass is heterogeneously enhancing throughout but gains signal with progression. There is distension of the fourth ventricle as the lesion progresses and increases in size.

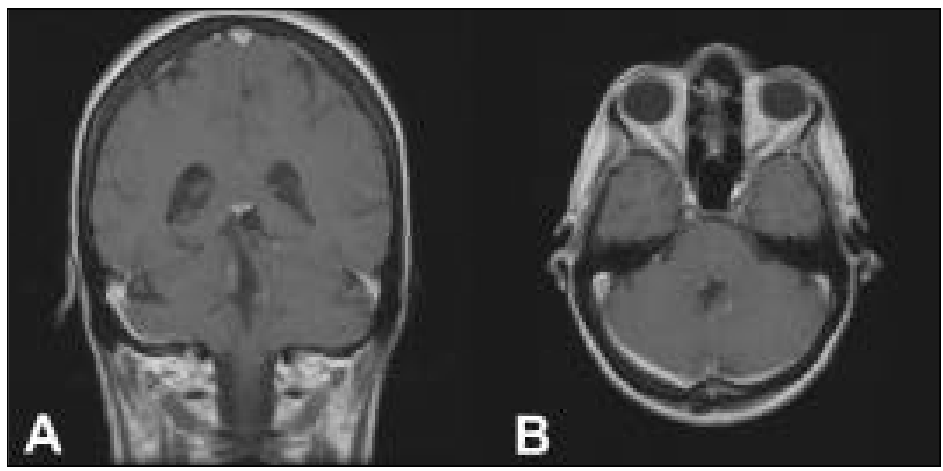

Figure 2: Postoperative gadolinium enhanced T1 weighted MRI images depicting incomplete resection of the fourth ventricular tumour. In both the coronal $(A)$ and axial $(B)$ images there is a rim of enhancement surrounding the area previously occupied by tumour. There is no evidence of additional tumour elsewhere in the ventricular system.

Figure 3: Postoperative gadolinium enhanced T1 weighted MRI images of the cervical spinal cord depicting a nodule of heterogeneously enhancing tissue on the ventral surface of the medulla. Arrows in the sagittal (A) and axial (B) images depict the anterolateral, right sided, location of the nodule which may correspond to disseminated disease.

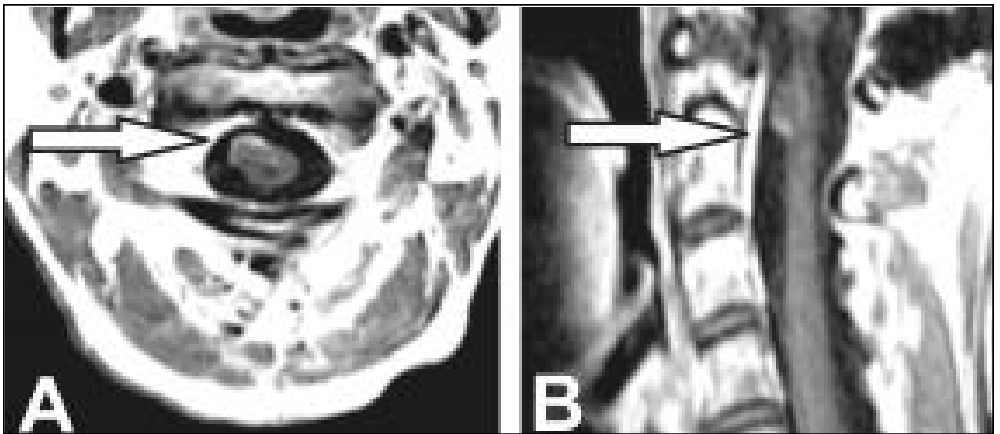

filament bundles were seen. There were no intercellular junctions and no synapses noted. Final diagnosis was central neurocytoma. Ki-67 immunohistochemistry was performed on all submitted tissue. Rare foci showed $1-2 \%$ positive nuclei, but most areas had below $1 \% \mathrm{Ki}-67$ immunopositivity; the consistency of labeling mitigates against the possibility that the tumour was insufficiently sampled. This is entirely in keeping with neurocytoma, and mitigates against a more sinister lesion. The lack of synaptophysin immunopositivity is unusual, but is supported by the absence of neurosecretory granules on electron microscopy.

\section{Radiation Therapy and Follow-up}

The patient experienced a period of severe depression which required psychiatric admission and delayed the start of radiation therapy. In view of the spinal cord seeding, radiation was initially administered to the whole of the craniospinal axis: 3600 cGy were delivered in 18 fractions over 3.5 weeks, with $6 \mathrm{MV}$ photons. This was followed by a boost dose to the tumour bed and upper cervical spine of a further $2000 \mathrm{cGy}$ in 10 fractions over two weeks. During the treatment she continued to require treatment of headache, nausea and vomiting. On review four months later these symptoms had abated and MRI showed improvement in the degree of enhancement of the residual tumour as well as disappearance of the lesion on the ventral medulla (Figure 5).

\section{Discussion}

Since the original description of central neurocytoma there have been several hundred cases reported. The present case displays several unusual findings for $\mathrm{CN}$. Neurocytoma of the 


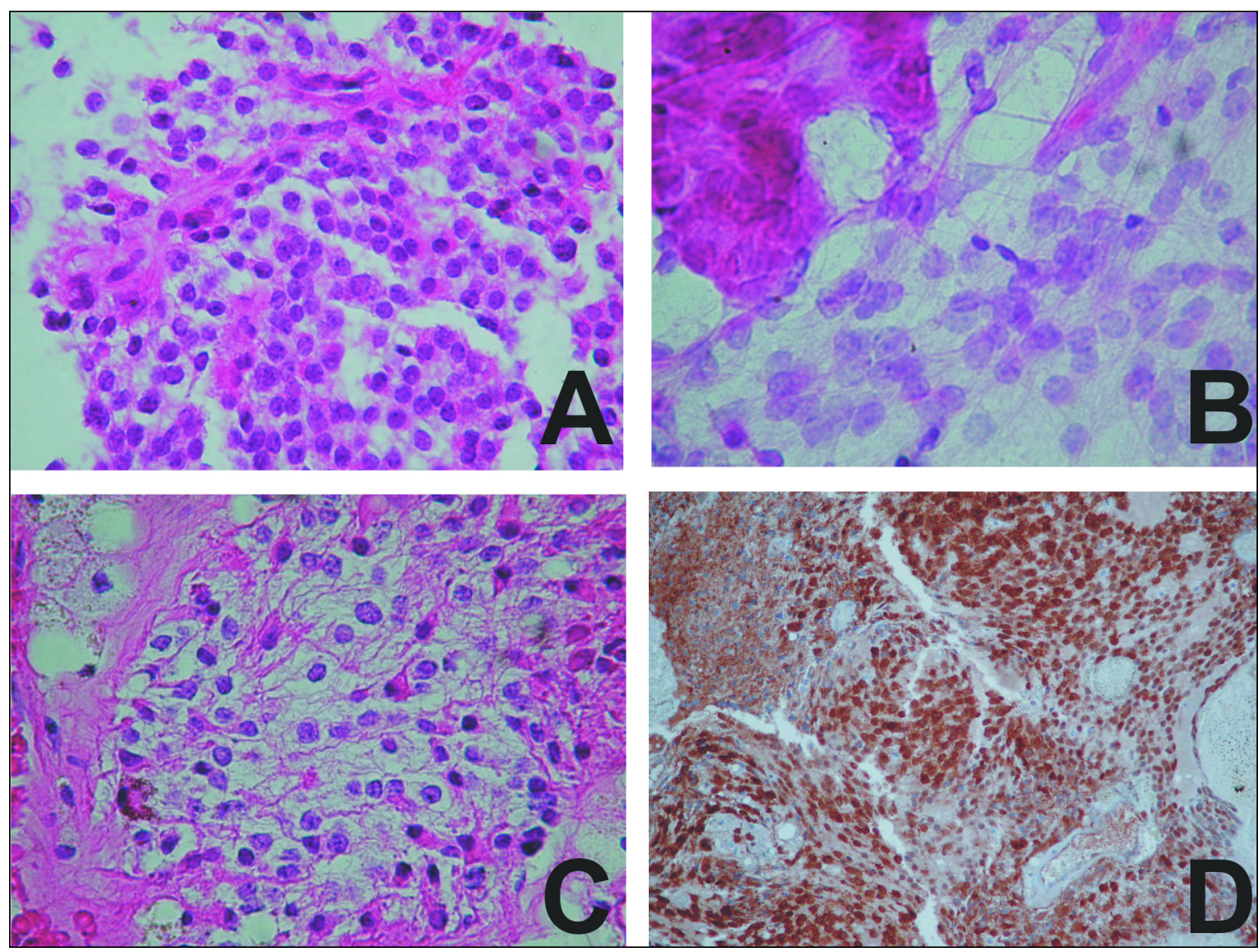

Figure 4: (A) Histology demonstrates hypercellular tissue with homogeneous round to ovoid cells arranged in non-descript sheets, slightly eosinophilic cytoplasm and salt and pepper chromatin patterning of the nuclei. (B) Smear sample demonstrates delicate processes. (C) There was some perinuclear clearing which is characteristic of this lesion. (D) Neuron specific enolase immunohistochemistry is strongly positive. Neurofilament, synaptophysin and glial fibrillary acidic protein staining were absent in the tumour sample (not depicted).

fourth ventricle is rare. We could find only two prior case reports. ${ }^{18,19}$ Both of these cases presented with obstructive hydrocephalus requiring immediate surgical treatment. Our patient initially had mild symptomatology and was not offered early intervention. However, the patient demonstrated gradual onset and worsening of obstructive symptomatology. Steroids prescribed over a three week period before the acute presentation leading to surgery were of no apparent benefit.

Our patient presented late in her sixth decade. Central neurocytoma classically arises in younger people; however, there are reports of people presenting with $\mathrm{CN}$ in their sixth and seventh decade. ${ }^{11,20-23}$ In terms of prognosis, a late age of onset has been shown to be a negative predictor of outcome. ${ }^{8}$

In this case, the appearance of the tumor on MRI fit the classic description of neurocytoma. ${ }^{1,7,8,10}$ The tumour was well demarcated, heterogeneously enhancing and possessed evidence of calcification. On surgical resection the tumor was found to be highly vascular. This is similar to the tumors described in the surgical case series by Yasargil. ${ }^{4}$ The local spread observed in our case was atypical for $\mathrm{CN}$. This pattern was reminiscent of the seeding observed in medulloblastoma. The resection was incomplete and enhancing tissue and seeding were observed on postoperative imaging. These findings suggest that our patient has a malignant variant of $\mathrm{CN}$. A case of $\mathrm{CN}$ that recurred with a highly malignant phenotype and associated seeding throughout

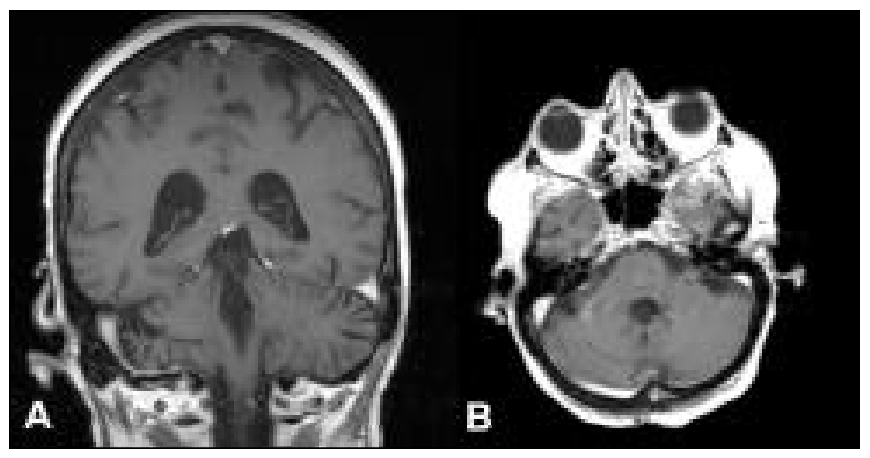

Figure 5: Gadolinium enhanced T1 images of the fourth ventricle. Coronal $(A)$ and axial $(B)$ images demonstrate significantly diminished enhancement of the fourth ventricular lesion. The enhancing nodule located on the ventral medulla had resolved at the time of this MRI (not shown). 
the ventricular system was reported by Elek et al. ${ }^{24}$ Aggressive $\mathrm{CN}$ with diffuse craniospinal dissemination has also been described in three additional cases. ${ }^{24-26}$ Less likely is an associated tumor, as in the case of right lateral ventricular $\mathrm{CN}$ associated with fourth ventricular medulloblastoma. ${ }^{27}$ The authors of this case suggest a common etiology in erroneous differentiation of granular cerebellar and ventricular progenitor cells that perpetuated the medulloblastoma and neurocytoma respectively. Although direct evidence to this effect is not available it is possible that our patient could harbor a similar lesion or a variant lesion with malignant properties.

The pathological differential diagnosis in the present case includes: (i) clear cell ependymoma (however no morphological, immunohistochemical or ultrastructural evidence of ependymal differentiation was detected), (ii) cerebellar liponeurocytoma, an indolent variant of medulloblastoma (this would require the identification of lipid in neoplastic cells which was absent in the present case, although limited sampling precludes ruling out this possibility entirely), (iii) the rosette forming and papillary glioneuronal tumours; these have distinct features which were absent in our case, and should exhibit distinct GFAP immunopositivity, which was not seen, and (iv) clear cell variants of meningioma and metastatic carcinoma (these were rejected on morphological grounds).

Chemotherapy has been used in recurrent disease in a few patients with equivocal outcomes. ${ }^{28,29}$ Stereotactic radiosurgery is being explored and has been used with good early results in recurrent/progressive $\mathrm{CN} .{ }^{30,31}$ Radiation has not been shown to statistically improve survival outcomes following incomplete resection, but has been shown to give significant local control of disease in the few studies completed to date. ${ }^{32-34}$ This may be due to the well-differentiated, indolent growth properties of $\mathrm{CN}$ which hypothetically make it less vulnerable to ionizing radiation. However, radiation is recommended when variant disease with a malignant phenotype is suspected or demonstrated. ${ }^{4}$ Therefore, our patient was treated secondarily with radiation. The $\mathrm{Ki}-67$ index in this tumour was low suggesting that sampling was adequate. It is possible that the tumour may behave less aggressively than would be predicted on the basis of neuroimaging and intraoperative findings. However, there has been limited follow-up in this case.

Synaptophysin staining is considered the most specific immunohistochemical marker for $\mathrm{CN} .{ }^{11}$ However, in this case, synaptophysin was negative while all of the other histological, immunohistochemical and ultrastructural studies were in support of $\mathrm{CN}$. There have been reports of $\mathrm{CN}$ without synaptophysin expression..$^{8,20,35,36}$ There have also been reports of technical limitations in synaptophysin staining that may yield falsenegative results. ${ }^{8,11}$ However, it has been shown that, in primitive neuroectodermal tumors, synaptophysin is expressed after neuron specific enolase and before neurofilament in the spectrum of differentiation from progenitor to neuronal phenotype. ${ }^{37}$ Central neurocytoma may arise from the same subependymal cell lineage as primitive neuroectodermal tumors, and this process would therefore be paralleled in $\mathrm{CN} .{ }^{23}$ Therefore, the tumor reported here may represent uniform differentiation of a $\mathrm{CN}$ at a stage prior to synaptophysin expression. There is one patient reported from a surgical series that originally had a synaptophysin negative $\mathrm{CN}$ resected and then had a recurrence with a synaptophysin positive $\mathrm{CN} .{ }^{20}$ This observation supports the idea of the tumor progressing to express synaptophysin in the late stages of differentiation. The cellular origin of $\mathrm{CN}$ is controversial. It was originally proposed that $\mathrm{CN}$ arose from the granular layer of the small gray nuclei of the septum pellucidum. ${ }^{1,8}$ This hypothesis was based on the anatomical association of $\mathrm{CN}$ with the wall of the lateral ventricle. Current evidence now supports the neural progenitor cells of the adult subependymal layer as the histogenic source for these tumours..$^{23,36,38,39}$ The subventricular zone persists into adulthood and remains active. ${ }^{40-42}$ It is implicated in the production of the progenitor cells of the rostral migratory stream and generation of olfactory interneurons. ${ }^{43,44}$ Proliferation in the ependymal layers of the spinal cord following injury has been described. ${ }^{45,46}$ There is also evidence that progenitor cells exist throughout the ventricular system of the entire neuraxis in rodent models. ${ }^{47-49}$ It is not yet clear whether these cells originate directly from the ependyma or arise in the subventricular zone or an as yet undescribed germinal center and migrate along the ependyma throughout the ventricular system. ${ }^{50}$ Regardless, it is plausible that $\mathrm{CN}$ may arise at any point in the ventricular system in either scenario. One would expect to rarely observe tumors outside of the lateral ventricle as the concentration of progenitor cells is significantly lower away from the subventricular zone. ${ }^{47}$ Supporting the ependymal progenitor hypothesis, $\mathrm{CN}$ has been observed arising from the ependymal component of a cystic ovarian teratoma. ${ }^{51}$ In rodent transplantation studies, progenitor cells have been observed to invade and persist intraparenchymally. ${ }^{52-54}$ These findings support a subependymal source for extraventricular $\mathrm{CN}$ by demonstrating the property of progenitor cells to invade nervous tissue. Hence, one explanation for the rare reports of cerebral, cerebellar and spinal neurocytoma is the case where a progenitor cell invades nervous tissue at any level in the ventricular system and proliferates as CN. Neural progenitor cells of the subependymal plate have been shown to be bipotential, generating glia and neurons. ${ }^{55-59}$ There have been several reports of $\mathrm{CN}$ with both synaptophysin and GFAP immunoreactivity. ${ }^{10,23}$ When neurocytoma cells are cultured, differentiation to a strongly GFAP positive phenotype occurs. ${ }^{60-62}$ A bipotential progenitor would account for this variation in marker expression in $\mathrm{CN}$ and fits with a subependymal or similar proliferative zone source.

This case demonstrates the rare occurrence of $\mathrm{CN}$ arising from the floor of the fourth ventricle. Serial imaging over a ten month period demonstrated slow growth and associated changes in tumor enhancement during this period. The management of this case was complicated by its location and vascularity. Moreover, the appearance of the tumor was suspicious for an invasive variant of $\mathrm{CN}$. In this case radiation was used in an attempt to control local progression of disease and prevent further craniospinal dissemination.

\section{REFERENCES}

1. Hassoun J, Gambarelli D, Grisoli F, et al. Central neurocytoma: an electron-microscopic study of two cases. Acta Neuropathol 1982;56:151-156.

2. Kleihues P, Burger PC, Scheithauer BW. The new WHO classification of brain tumours. Brain Pathol 1993;3:255-268.

3. Figarella-Branger D, Soylemezoglu F, Kleihues P, Hassoun J. 
Central neurocytoma. In: Kleihues $\mathrm{P}$, Cavenee WK, (Eds). Pathology and Genetics of Tumours of the Nervous System, 2nd ed. Lyon, France: IARC Press, 2000: 107-109.

4. Yasargil MG, von Ammon K, von Deimling A, et al. Central neurocytoma: histopathological variants and therapeutic approaches. J Neurosurg 1992;76:32-37.

5. Hassoun J, Soylemezoglu F, Gambarelli D, et al. Central neurocytoma: a synopsis of clinical and histological features. Brain Pathol 1993;3:297-306.

6. Sgouros S, Carey M, Aluwihare N, et al. Central neurocytoma: a correlative clinicopathologic and radiologic analysis. Surg Neurol 1998;49:197-204.

7. Bolen JW Jr, Lipper MH, Caccamo D. Intraventricular central neurocytoma: CT and MR findings. J Comput Assist Tomogr 1989;13:495-497.

8. Figarella-Branger D, Pellissier JF, Daumas-Duport C, et al. Central neurocytomas. Critical evaluation of a small-cell neuronal tumor. Am J Surg Pathol 1992;16:97-109.

9. Giangaspero F, Cenacchi G, Losi L, et al. Extraventricular neoplasms with neurocytoma features. A clinicopathological study of 11 cases. Am J Surg Pathol 1997;21:206-212.

10. Ishiuchi $\mathrm{S}$, Tamura $\mathrm{M}$. Central neurocytoma: an immunohistochemical, ultrastructural and cell culture study. Acta Neuropathol 1997;94:425-435.

11. Robbins P, Segal A, Narula S, et al. Central neurocytoma. A clinicopathological, immunohistochemical and ultrastructural study of 7 cases. Pathol Res Pract 1995;191:100-111.

12. Brat DJ, Scheithauer BW, Eberhart CG, et al. Extraventricular neurocytomas: pathologic features and clinical outcome. Am J Surg Pathol 2001;25:1252-1260.

13. Buccoliero AM, Caldarella A, Ammannati F, et al. Extraventricular neurocytoma: morphological and immunohistochemical considerations on differential diagnosis. Pathol Res Pract 2002;198:627-633.

14. Coca S, Moreno M, Martos JA, et al. Neurocytoma of spinal cord. Acta Neuropathol 1994;87:537-540.

15. Enam SA, Rosenblum ML, Ho KL. Neurocytoma in the cerebellum. Case report. J Neurosurg 1997;87:100-102.

16. Tatter SB, Borges LF, Louis DN. Central neurocytomas of the cervical spinal cord. Report of two cases. J Neurosurg 1994;81:288-293.

17. Tatter SB, Borges LF, Louis DN. Correction: central neurocytomas of the cervical spinal cord. J Neurosurg 1995;82:706

18. Hsu PW, Hsieh TC, Chang CN, et al. Fourth ventricle central neurocytoma: case report. Neurosurgery 2002;50:1365-1367.

19. Warmuth-Metz M, Klein R, Sorensen N, et al. Central neurocytoma of the fourth ventricle. J Neurosurg 1999;91:506-509.

20. Fujisawa H, Marukawa K, Hasegawa M, et al. Genetic differences between neurocytoma and dysembryoplastic neuroepithelial tumor and oligodendroglial tumors. J Neurosurg 2002;97:13501355.

21. Kim DG, Kim JS, Chi JG, et al. Central neurocytoma: proliferative potential and biological behavior. J Neurosurg 1996;84:742-747.

22. Mackenzie IR. Central neurocytoma: histologic atypia, proliferation potential, and clinical outcome. Cancer 1999;85:1606-1610.

23. von Deimling A, Janzer R, Kleihues P, et al. Patterns of differentiation in central neurocytoma. An immunohistochemical study of eleven biopsies. Acta Neuropathol 1990;79:473-479.

24. Elek G, Slowik F, Eross L, et al. Central neurocytoma with malignant course. Neuronal and glial differentiation and craniospinal dissemination. Pathol Oncol Res 1999;5:155-159.

25. Eng DY, DeMonte F, Ginsberg L, et al. Craniospinal dissemination of central neurocytoma. Report of two cases. J Neurosurg 1997;86:547-552.

26. Takao H, Nakagawa K, Ohtomo K. Central neurocytoma with craniospinal dissemination. J Neurooncol 2003;61:255-259.

27. Horoupian DS, Shuster DL, Kaarsoo-Herrick M, et al. Central neurocytoma: one associated with a fourth ventricular PNET/medulloblastoma and the second mixed with adipose tissue. Human Pathol 1997;28:1111-1114.

28. Brandes AA, Amista P, Gardiman M, et al. Chemotherapy in patients with recurrent and progressive central neurocytoma. Cancer 2000;88:169-174.
29. Dodds D, Nonis J, Mehta M, et al. Central neurocytoma: a clinical study of response to chemotherapy. J Neurooncol 1997;34:279-283.

30. Kim CY, Paek SH, Kim DG. Linear accelerator radiosurgery for central neurocytoma: a case report. J Neurooncol 2003;61:249-254.

31. Pollock BE, Stafford SL. Stereotactic radiosurgery for recurrent central neurocytoma: case report. Neurosurgery 2001;48:441443.

32. Rades D, Fehlauer F. Treatment options for central neurocytoma. Neurology 2002;59:1268-1270.

33. Rades D, Schild SE, Ikezaki K, et al. Defining the optimal dose of radiation after incomplete resection of central neurocytomas. Int J Radiat Oncol Biol Physics 2003;55:373-377.

34. Schild SE, Scheithauer BW, Haddock MG, et al. Central neurocytomas. Cancer 1997;79:790-795.

35. Barbosa MD, Balsitis M, Jaspan $\mathrm{T}$, et al. Intraventricular neurocytoma: a clinical and pathological study of three cases and review of the literature. Neurosurgery 1990;26:1045-1054.

36. Kubota T, Hayashi M, Kawano $\mathrm{H}$, et al. Central neurocytoma: immunohistochemical and ultrastructural study. Acta Neuropathol 1991;81:418-427.

37. Burger PC, Grahmann FC, Bliestle A, et al. Differentiation in the medulloblastoma. A histological and immunohistochemical study. Acta Neuropathol 1987;73:115-123.

38. Nishio S, Fujiwara S, Tashima T, et al. Tumors of the lateral ventricular wall, especially the septum pellucidum: clinical presentation and variations in pathological features. Neurosurgery 1990;27:224-230.

39. von Deimling A, Kleihues P, Saremaslani P, et al. Histogenesis and differentiation potential of central neurocytomas. Lab Invest 1991;64:585-591.

40. Altman JD, Das GD. Autoradiographic and histological evidence of postnatal hippocampal neurogenesis in rats. J Compar Neurol 1965; 124:319-335.

41. Fujita S. The matrix cell and cytogenesis in the developing central nervous system. J Compar Neurol 1963;120:37-42.

42. Smart I. The subependymal layer of the mouse brain and its cell production as shown by radioautography after $[3 \mathrm{H}]$ thymidine injection. J Compar Neurol 1961;116:325-427.

43. Kornack DR, Rakic P. The generation, migration, and differentiation of olfactory neurons in the adult primate brain. Proc Nat Acad Sci USA2001;98:4752-4757.

44. Morshead CM, Reynolds BA, Craig CG, et al. Neural stem cells in the adult mammalian forebrain: a relatively quiescent subpopulation of subependymal cells. Neuron 1994;13:1071-1082.

45. Kojima A, Tator $\mathrm{CH}$. Intrathecal administration of epidermal growth factor and fibroblast growth factor 2 promotes ependymal proliferation and functional recovery after spinal cord injury in adult rats. J Neurotrauma 2002;19:223-238.

46. Namiki J, Tator $\mathrm{CH}$. Cell proliferation and nestin expression in the ependyma of the adult rat spinal cord after injury. J Neuropathol Exper Neurol 1999;58:489-498.

47. Alonso G. Neuronal progenitor-like cells expressing polysialylated neural cell adhesion molecule are present on the ventricular surface of the adult rat brain and spinal cord. J Comp Neurol 1999;414:149-166.

48. Laywell ED, Kukekov VG, Steindler DA. Multipotent neurospheres can be derived from forebrain subependymal zone and spinal cord of adult mice after protracted postmortem intervals. Exp Neurol 1999;156:430-433.

49. Weiss S, Dunne C, Hewson J, et al. Multipotent CNS stem cells are present in the adult mammalian spinal cord and ventricular neuroaxis. J Neurosci 1996;16:7599-7609.

50. Johansson CB, Momma S, Clarke DL, et al. Identification of a neural stem cell in the adult mammalian central nervous system. Cell 1999;96:25-34

51. Hirschowitz L, Ansari A, Cahill DJ, et al. Central neurocytoma arising within a mature cystic teratoma of the ovary. Int $\mathbf{J}$ Gynecol Pathol 1997;16:176-179.

52. Bai H, Suzuki Y, Noda T, et al. Dissemination and proliferation of neural stem cells on the spinal cord by injection into the fourth ventricle of the rat: a method for cell transplantation. J Neurosci Methods 2003;124:181-187.

53. Englund U, Bjorklund A, Wictorin K, et al. Grafted neural stem cells 
develop into functional pyramidal neurons and integrate into host cortical circuitry. Proc Nat Acad Sci USA2002;99:17089-17094.

54. Riess P, Zhang C, Saatman KE, et al. Transplanted neural stem cells survive, differentiate, and improve neurological motor function after experimental traumatic brain injury. Neurosurgery 2002;51:1043-1052.

55. Chiasson BJ, Tropepe V, Morshead CM, et al. Adult mammalian forebrain ependymal and subependymal cells demonstrate proliferative potential, but only subependymal cells have neural stem cell characteristics. J Neurosci 1999;19:4462-4471.

56. Kukekov VG, Laywell ED, Suslov O, et al. Multipotent stem/ progenitor cells with similar properties arise from two neurogenic regions of adult human brain. Exp Neurol 1999;156:333-344.

57. Luskin MB. Restricted proliferation and migration of postnatally generated neurons derived from the forebrain subventricular zone. Neuron 1993;11:173-189.
58. Reynolds BA, Weiss S. Generation of neurons and astrocytes from isolated cells of the adult mammalian central nervous system. Science 1992;255:1707-1710.

59. Steindler DA, Kadrie T, Fillmore H, et al. The subependymal zone: "brain marrow". Prog Brain Res 1996;108:349-363.

60. Ishiuchi S, Nakazato $\mathrm{Y}$, Iino $\mathrm{M}$, et al. In vitro neuronal and glial production and differentiation of human central neurocytoma cells. J Neurosci Res 1998;51:526-535.

61. Westphal M, Meissner H, Matschke J, et al. Tissue culture of human neurocytomas induces the expression of glial fibrilary acidic protein. J Neurocytol 1998;27:805-816.

62. Westphal M, Stavrou D, Nausch H, et al. Human neurocytoma cells in culture show characteristics of astroglial differentiation. J Neurosci Res 1994; 38:698-704. 